\title{
European countries with delayed childbearing are not those with lower fertility
}

\author{
Éva Beaujouan ${ }^{1 *}$ and Laurent Toulemon ${ }^{2}$ (D)
}

\author{
* Correspondence: eva.beaujouan@ \\ univie.ac.at \\ ${ }^{1}$ University of Vienna, Wittgenstein \\ Centre for Demography and Global \\ Human Capital (IIASA, OeAW, \\ University of Vienna), Vienna, Austria \\ Full list of author information is \\ available at the end of the article
}

\begin{abstract}
At the individual level, a very strong negative relationship is observed between age at first birth and total number of children. However, at the country level, it is possible that no relationship exists between factors that reduce fertility at younger ages and stimulate it at older ages. Hence, across countries, the size of the decline in youth fertility is potentially unrelated to the size of the increase in fertility at older ages or the decline in total fertility. We study the fertility of women and their age at childbirth, with particular attention to their evolution over the last 40 years in countries across Europe. Comparing these countries, the increase in births after age 30 has occurred relatively independently of the decline at younger ages according to both period and cohort, and we find no positive relationship between the delay of first birth and decline in total fertility. On the contrary, an inverse relationship evidently exists at the country level, as longer delays generally correspond to smaller declines in total fertility. Context effects largely dominate individual constraints and play an important role in the occurrence of later births.
\end{abstract}

Keywords: Birth delay, Mean age at first birth, Fertility rate, Late fertility, Europe

\section{Introduction}

Since the mid-1970s, the average maternal age at birth has been rising in most European countries (Frejka \& Sobotka, 2008; Mills, Rindfuss, Mcdonald, Velde, \& Force, 2011). This general trend is primarily the result of a fertility decline among young women, which in turn has been induced by the spread of effective contraceptive methods (Lesthaeghe, 2016; Nathan \& Pardo, 2019). The increase in maternal age at childbirth overall has been interpreted as resulting from first birth "postponement". This postponement dynamic, followed by a full or partial catch-up of births within cohorts, implies that people postpone having children for a given reason (e.g. further education) while continuing to anticipate becoming parents (Neels \& De Watcher, 2010; Sobotka, Zeman, Lesthaeghe, Frejka, \& Neels, 2011). Another possible interpretation at the population level is that two distinct phenomena are occurring without necessarily any empirical or causal relationship between them (Ní Bhrolcháin \& Toulemon, 2005), namely that fertility is decreasing at young ages while independently

(c) The Author(s). 2021 Open Access This article is licensed under a Creative Commons Attribution 4.0 International License, which permits use, sharing, adaptation, distribution and reproduction in any medium or format, as long as you give appropriate credit to the original author(s) and the source, provide a link to the Creative Commons licence, and indicate if changes were made. The images or other third party material in this article are included in the article's Creative Commons licence, unless indicated otherwise in a credit line to the material. If material is not included in the article's Creative Commons licence and your intended use is not permitted by statutory regulation or exceeds the permitted use, you will need to obtain permission directly from the copyright holder. To view a copy of this licence, visit http://creativecommons.org/licenses/by/4.0/. 
increasing at older ages. In such cases, each woman has her own particular reasons for not having children when young and for whether or not to become a mother when older.

An abundance of individual and contextual factors affects fertility (Balbo, Billari, \& Mills, 2013), each of them having potentially distinct interactions at young and older ages. The fertility decline at young ages-say before age 30-has been described as a result of various upheavals since the 1970s: delayed completion of education (Neels, Murphy, Ní Bhrolcháin, \& Beaujouan, 2017; Ní Bhrolcháin \& Beaujouan, 2012), the rise of effective contraceptive methods and the legalized option of aborting an unplanned pregnancy (Bajos, Prioux, \& Moreau, 2013; Goldin \& Katz, 2002; Toulemon \& Leridon, 1992), willingness to live in a couple before considering parenthood (Mazuy, 2006), and difficulties in entering the labour market or choosing to invest in one's professional career before having children (Kreyenfeld, Andersson, \& Pailhé, 2012).

The increase in fertility at older ages may be a response to some of these factors. For instance, the general increase in age at the end of studies automatically resulted in postponed first births (Ní Bhrolcháin \& Beaujouan, 2012). In addition, the increase in births beyond age 30 may be linked to other individual and contextual factors (Neels, Theunynck, \& Wood, 2012; Sánchez-Barricarte \& Fernández-Carro, 2007). For example, individual couple trajectories have changed significantly in recent decades as first unions occur later and re-partnering occurs following relationship breakdowns (with or without children), by which an increasing proportion of newly formed couples may wish to have a child at older ages (Beaujouan, 2011; Thomson, Lappegård, Carlson, Evans, \& Gray, 2014; Thomson, Winkler-Dworak, Spielauer, \& Prskawetz, 2012; Van Bavel, Jansen, \& Wijckmans, 2012). A set of conditions conducive to later fertility has been created by general improvements in health (Vallin \& Meslé, 2004), progress in pregnancy monitoring, and the reduced risks of childbirth (Kotelchuck, 2007; Prioux, 2004). Finally, effective ways of reconciling family and professional life directly promote the fertility of couples already pursuing careers (Thévenon \& Gauthier, 2011), specifically in the form of reduced-cost childcare being widely available, family allowances, other compensation for lost income, enhanced job security, and flexible work arrangements.

The above factors clearly indicate not only that context is a central element of fertility trends, but also that shifts at young and older ages can occur quite independently of each other. Furthermore, the reasons for fertility variations across countries are not all known in the literature, which nevertheless cites the roles of norms, social pressure, and individual values even though these are difficult to demonstrate (Arpino, Espingandersen, \& Pessin, 2015; Lesthaeghe, 2010; Liefbroer \& Billari, 2010). Yet, some factors have been more firmly established (Balbo et al., 2013); for example, international differences in the timing of first births can be partly attributed to differences in age at completion of education and entry into the labour market (Nicoletti \& Tanturri, 2008). Various family policies also seem to favour births under certain conditions (Luci-Greulich \& Thévenon, 2013), and cyclical economic conditions can slow or accelerate births (Neels et al., 2012; Sobotka, Skirbekk, \& Philipov, 2011). Stated briefly, a wide variety of cultural and economic contexts can be found among European countries, where states do not always play the same role (Esping-Andersen, 2009; Gauthier, 2002). It can therefore be expected that fertility trends will differ from one country to another and that variations between countries may not be similar for older and younger ages. 
Due to the widespread fertility decline at young ages, Europe as a whole experienced a simultaneous increase in mean age at birth and decline in total fertility rate (TFR). At the individual level, fertility decline at young ages is often described as postponement and an increase at older ages as recuperation. We could thus expect that a larger fertility decline at young ages leads to a larger increase at older ages. However, births compete with other activities and preferences as individual trajectories progress (Philipov, 2009; Rybińska, Tocchioni, Matysiak, Vignoli, \& Mynarska, 2012; Testa \& Rampazzo, 2018). Thus, as the delay in first birth becomes longer, the likelihood of childlessness becomes greater and the number of children at older ages is likely to become smaller (Beaujouan, Reimondos, Gray, Evans, \& Sobotka, 2019; Castro, 2014; Habbema, Eijkemans, Leridon, \& te Velde, 2015; Tomkinson, 2019). te Velde, Habbema, Leridon, and Eijkemans (2012) show that delayed births cause a slightly reduced TFR, with variations according to country. Such circumstances inform our first hypothesis, which is that recuperation will be only partial, thus leading to a decrease in fertility rates as mean age at first birth increases, when taking both period and cohort perspectives (Lesthaeghe, 2016).

As presented above, a strong relationship exists at the individual level between age at first birth and the final number of children. Yet, while this relationship is valid for individuals, it does not necessarily persist at the population scale, such as when comparing countries (Billari, Manfredi, \& Valentini, 2000). Thus, we argue that-for social, normative, economic, and policy reasons-no relationship exists between the increase at old ages and the decline at young ages when comparing countries. This leads to our second hypothesis that neither the decrease in fertility rates nor the increase in fertility at older ages is positively related to the magnitude of postponement across countries. What is more, greater flexibility in childbearing schedules may correspond to having more children at older ages, irrespective of the fertility decline at young ages, thereby resulting in a positive relationship between the increases in mean age and fertility rates when comparing countries. According to this hypothesis, the relationship observed at the individual level becomes irrelevant in a cross-country perspective when analysing fertility trends across European countries.

\section{Data and methods}

We use primarily aggregate fertility data from European countries disseminated by Eurostat's database ${ }^{1}$ and the Human Fertility Database (Max Plank Institute for Demographic Research and Vienna Institute of Demography) (Jasilioniene et al., 2007). Wherever this aggregate European data is insufficient, we use country-specific data provided directly from national institutes.

Aside from the standard fertility indicators of TFR and mean age at birth ${ }^{2}$ that contextualize our study, we use age-specific fertility rates (ASFRs) to better detail the effects of delayed births on fertility in recent decades. Specifically, we detail fertility at ages 15-29 and 30-49 by measuring the sum of the ASFRs in these age groups and the

\footnotetext{
${ }^{1}$ https://ec.europa.eu/eurostat/data/database

${ }^{2}$ The TFR is calculated by summing single-year age-specific fertility rates in a given period. It summarizes the final lifetime average number of children born to a fictitious cohort of women spending their reproductive lives in this given period and having, at each age, the fertility of women of that age during the considered period. Mean age at birth is also calculated based on age-specific fertility rates for each year.
} 
partial TFRs at ages below and above 30. We also compare changes in the timing of fertility and changes in fertility rates between birth cohorts, with a focus on average age at the birth of the first child and average number of children within cohorts. We detail country- and cohort-variation in the link between cohort mean age at first birth, the proportion of women remaining childless, and the average number of children per mother.

\section{Various ways to delay births in Europe}

In France, 1976 was notable for being the year when TFR stabilized after a 10-year decline due to the baby boom having ended (Toulemon \& Mazuy, 2001). Since then, TFR has remained more or less stable at around 1.9 children per woman, while the average maternal age at birth has increased rapidly (Mazuy, Barbieri, Breton, \& D'Albis, 2015, table A.4) as a 4-year increase in mean age at birth has occurred over the past four decades (Fig. 1). Beginning with the 1977 minimum of 26.5 years, the mean age in France rose very quickly to 29.1 years in 1996 (an increase of 2.6 years in less than 20 years), then reached 30.6 years in 2016 at a slower rate (1.4 years in 20 years). This increase forms part of a general trend of delayed demographic events, particularly the delay of death. Women's life expectancy at birth increased by 8 years over this same 40-year period, from 77.2 to 85.3 years (Insee, 2019); because infant mortality was already low in 1976, most of these years were gained in adulthood as life expectancy at 15 years increased by 7.3 years. This life expectancy increase may therefore induce and even explain the delay in certain stages of adult life: a later death not only implies living more years into old age, but also more years as an adult, which may particularly explain the current delayed transition of young people to adulthood (Billari \& Liefbroer, 2010).

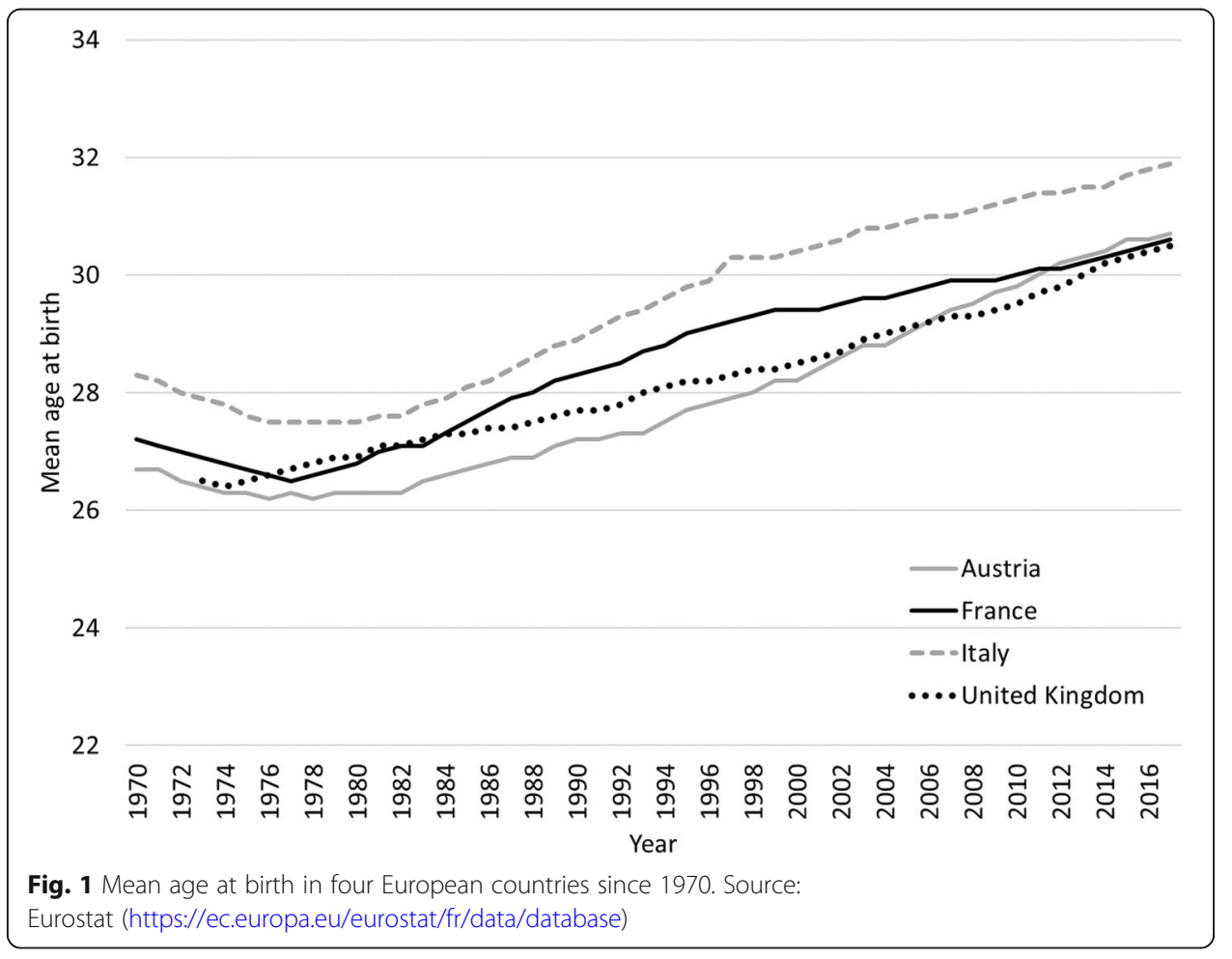


Figure 1 also shows the average maternal age at childbirth in three European countries (Austria, Italy, and the UK) that are comparable to France in terms of mortality and economic development. By the 1970s, in Italy, this age was already slightly higher than in other countries and continued to increase in parallel with France until the end of the 1990s, when the increase slowed down slightly in Italy and more strongly in France. Conversely, the increase in mean age at birth occurred more slowly and later in Austria and the UK than in France-although, just as in 1977, all three countries converge to similar mean ages (around 30.6 years) in 2017 while births continue to take place later in Italy.

The increase in mean age at birth after the baby boom is accompanied by a relatively stable TFR in all four countries. The decline related to the end of the baby boom ends in the mid-1970s for the UK and France, then later in the mid-1980s for Italy and Austria. Between 1987 and 2017, the mean age increases dramatically (between 2.8 and 3.8 years, around 2 months per year), while the overall changes in the TFR constitute less than 0.1 children per woman. The TFR remains nearly constant at a lower level in Italy and Austria (1.3 and 1.5 children per woman, respectively) than in the UK and France (1.7 and 1.9, respectively) (Fig. 2). The slight decrease observed between 1977 and 1997 is offset by the increase that follows until the end of the 2000s. The 2008 crisis led to a further decline in most countries (Matysiak, Sobotka, \& Vignoli, 2018; Sobotka, Skirbekk, \& Philipov, 2011), with Austria being the exception thanks to their proactive policy for increasing the number of early childcare facilities (Sobotka, 2016).

While the variations in general indicators have remained close over the past 40 years in these four countries, a detailed examination of fertility rates by age shows different trends (Fig. 3). Looking at the ages at which high fertility rates (more than seven children per year per hundred women) are observed in France, these ranged from 19 to 31

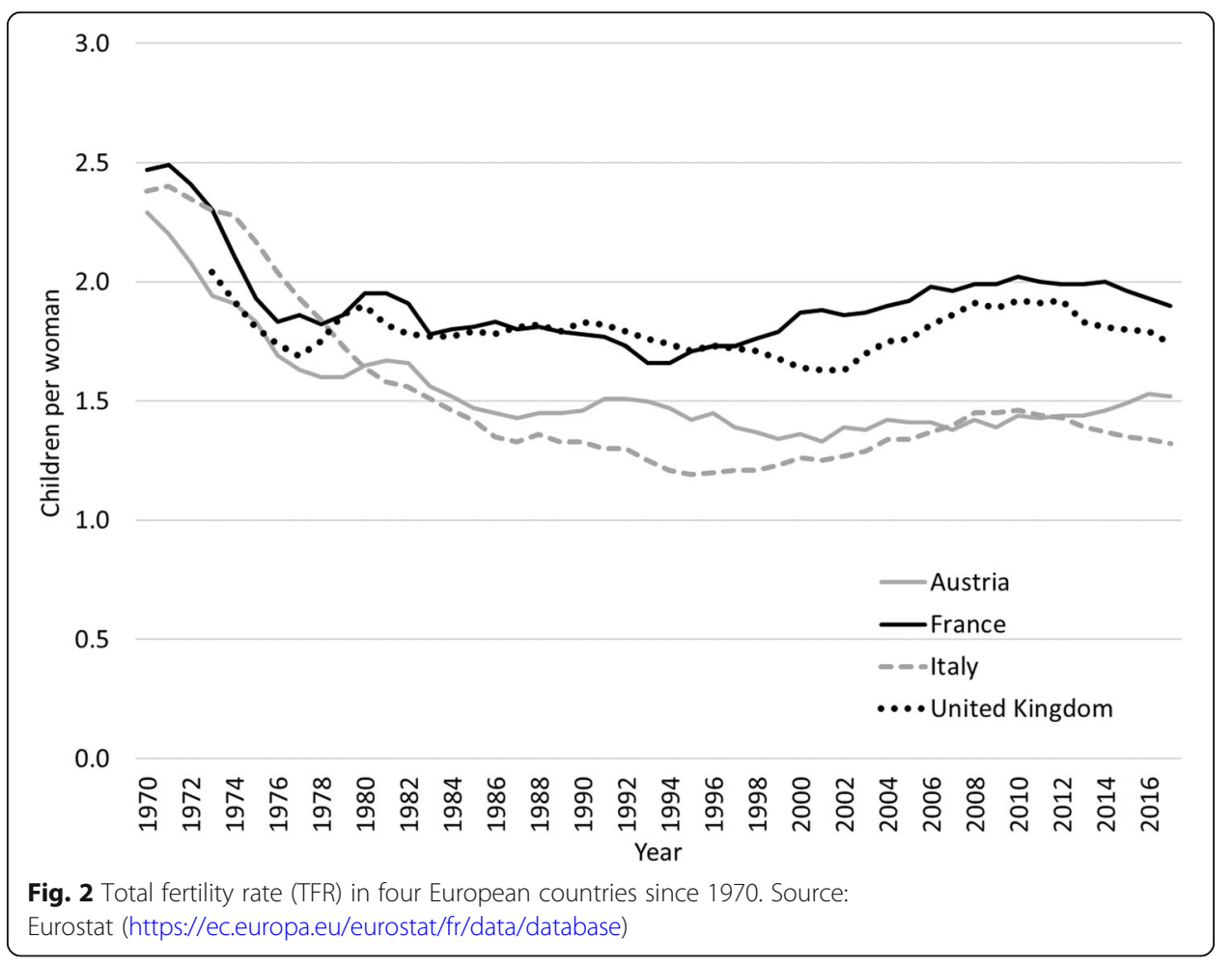




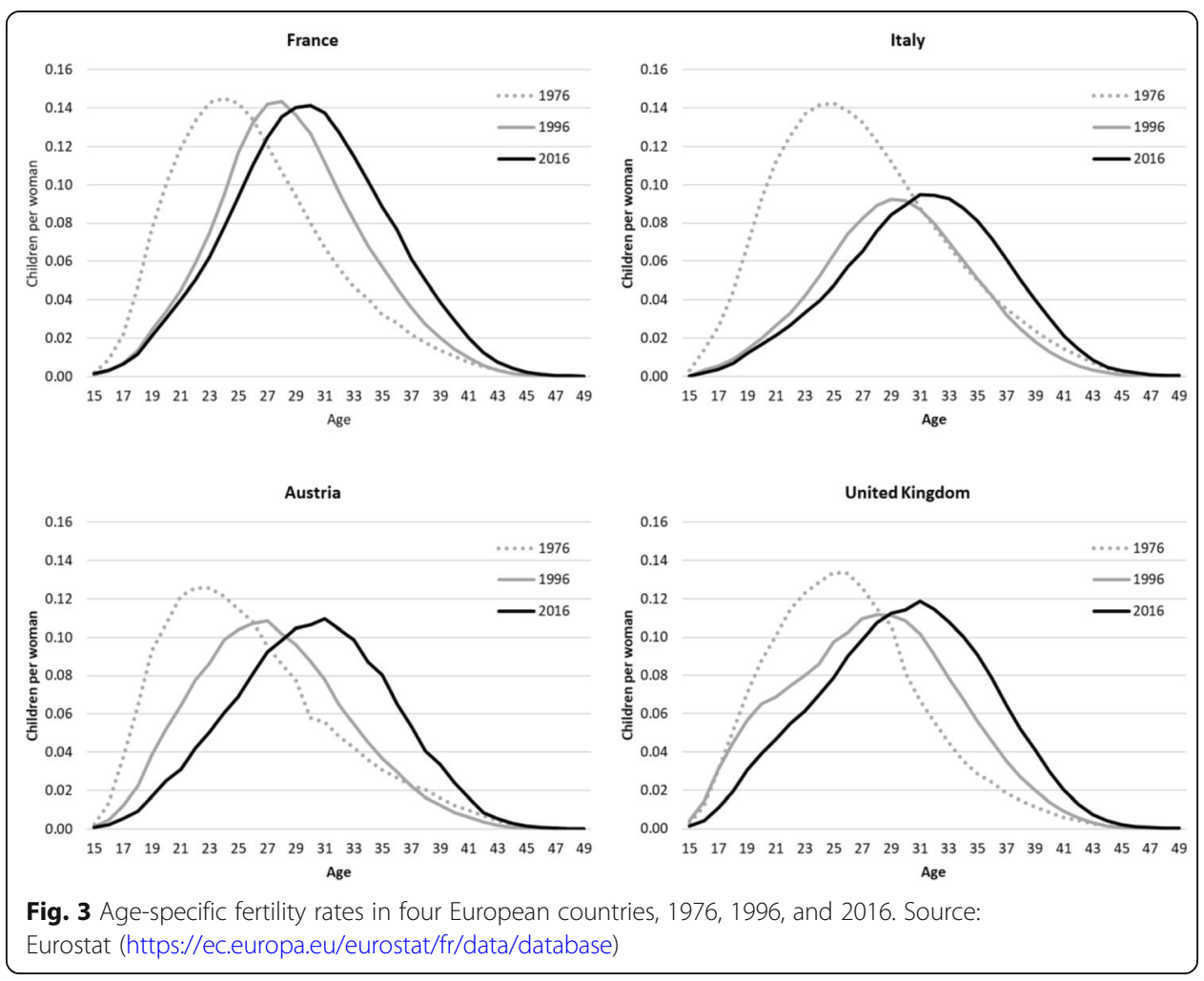

years in 1976, then 23 to 34 in 1996. There, the evolution of these rates appears to be a simple matter of translating births to older ages, but the significant decrease at young ages is only partially offset by the increase at older ages (the curve no longer spreads as much into older ages). In the following decades, the gap grows smaller and the decline at younger ages stops-notably, at the same time as the increase in average age of ending studies-while the rise at older ages continues almost as strongly as in the previous decades (fertility is higher than seven children per hundred women at ages 24 to 36 in 2016). One could say that the delay is partially compensated for from 1976 to 1996 and even more so from 1996 to 2016. Fertility at modal age (the age at which it is highest) remains stable: $14 \%$ of women aged 24 gave birth in the year 1976, aged 28 in 1996, and 30 in 2016.

While the other three countries still shift towards older ages, they also reflect their own specificities when compared to France. The decline at young ages in Italy is not accompanied by any increase after age 30 between 1976 and 1996, and the TFR decreases significantly (from 1.9 to 1.2 children per woman during this period). The increase after age 30 begins in the following period, but the TFR remains at a low level (1.3). The trends in Austria and the UK are closer to those observed in France, although the decline at young ages is more regular and pronounced in Austria while its increase at older ages is lower. Modal fertility in Austria has not exceeded $11 \%$ in recent years. In the UK, the decline before age 20 has been very slow, with teenage pregnancies remaining frequent in the 1980s and 1990s, despite a decline before and increase after age 30. Furthermore, teenage fertility in the UK fell dramatically in the 2000s, and the trend towards later childbearing is more regular across ages as they remain more dispersed than in the other countries. 
This overview of four countries shows that while the average age at childbearing is increasing in all countries, trends and fertility rates appear to vary greatly. We thus explore our hypotheses for other European countries, starting with the relationship between the decline in fertility rates at younger ages and the increase at older ages. Data for recent years are available for a large number of countries, thus enabling a comparison of changes in partial fertility rates by summing age-specific rates from, on the one hand, ages 15 to 29 and, on the other, above age 30. Figure 4 compares fertility trends before and after age 30 in a large number of European countries for the years 1996 to 2016.

In all the countries observed here, fertility declines before and increases after age 30 over the period 1996-2016. However, the increase is more pronounced in countries with a more moderate decline rather than in countries where it is greatest and which therefore have the most catching up to do. This comparison could be refined by considering that the fertility decline at young ages did not begin concurrently in all countries, but it already confirms our second hypothesis for the 20-year period of 19962016, namely that while the underlying reasons for delaying and catching up may be meaningful at the individual level, they do not account for the variability of developments in various countries.

In addition, if a generation of women falls behind at earlier ages, they only catch up with a certain lag. A weak albeit positive relationship exists between the 1996-2006 decline before age 30 and the 2006-2016 increase after age 30 (results not shown), but a counterfactual test using a negative lag shows very similar results for this decline and increase, because the European countries in our study are not homogenous. Thus, the

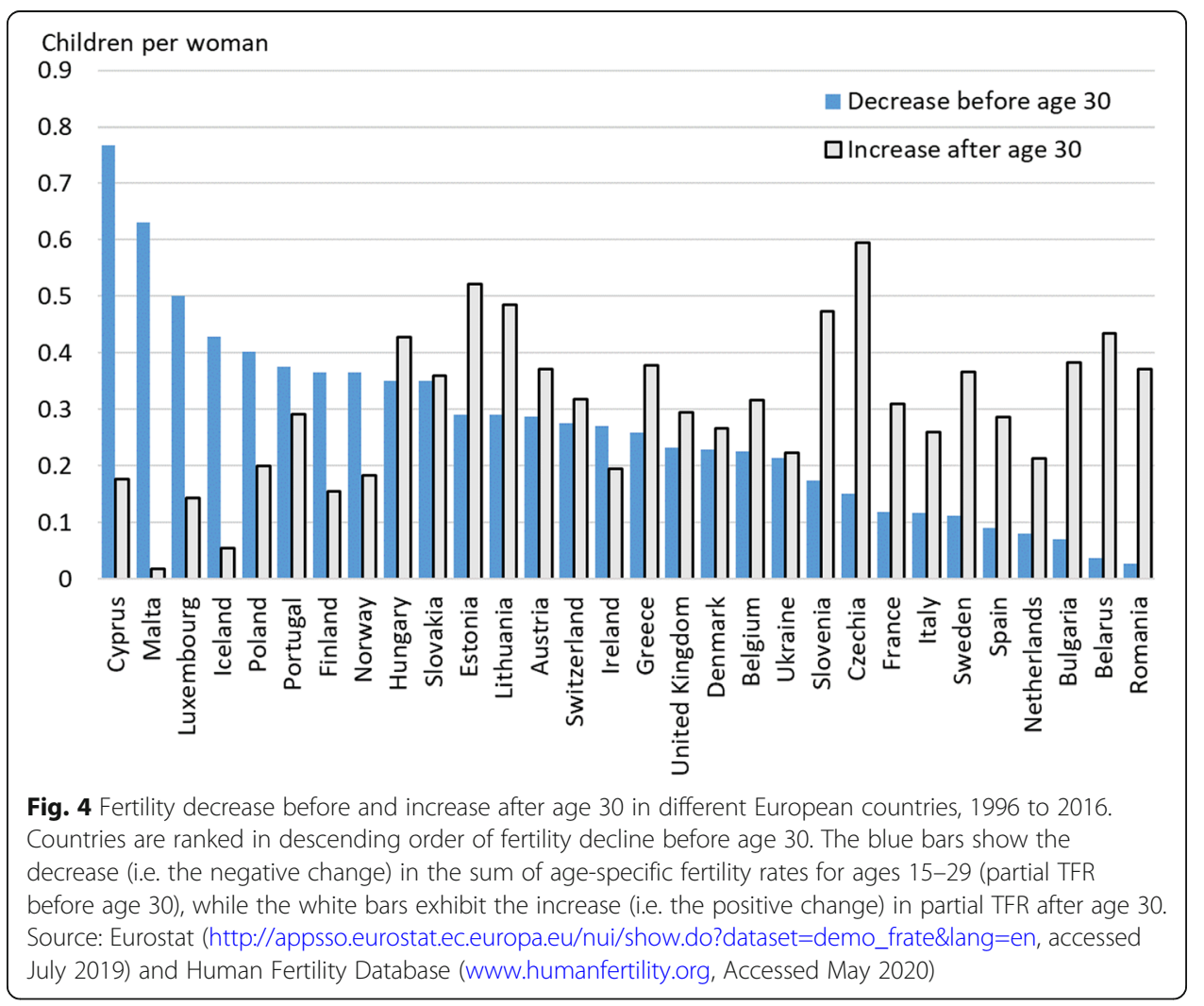


decline at younger ages occurs simultaneously with the increase at older ages over the period 1996-2016, but lagged period changes are not convincingly related.

\section{Delay and catch-up: a pattern that does not exist in cohorts}

To determine whether the delay and catch-up pattern exists at the aggregate level, we analyse fertility over cohorts of women identified by year of birth in European countries. Figure 5 compares the average age at first birth and the average number of live births to women born in 1952, 1962, and 1972. These birth cohorts are, respectively, 65, 55, and 45 years old in 2017; all turned 20 between 1972 and 1992; and they gave birth to their children after the baby boom years. In all cohorts, the average number of children is not systematically lower among countries with higher mean age at first birth, nor is the decrease in mean fertility from one cohort to the next always stronger where the increase in age is larger. Thus, unlike at the individual level, no relationship is observed when comparing countries.

Breaking these trends down further, we identify three groups of countries according to decrease in number of children born per woman and delay in childbearing. Italy and Spain are characterized by a sharp increase in the mean age at first birth and a sharp decline in completed fertility, by which the highly significant fertility decline at younger ages is not offset by an increase at older ages (see Fig. 9). A similar trend occurs in Poland and, to a lesser extent, in Hungary and Austria. This group constitutes a small

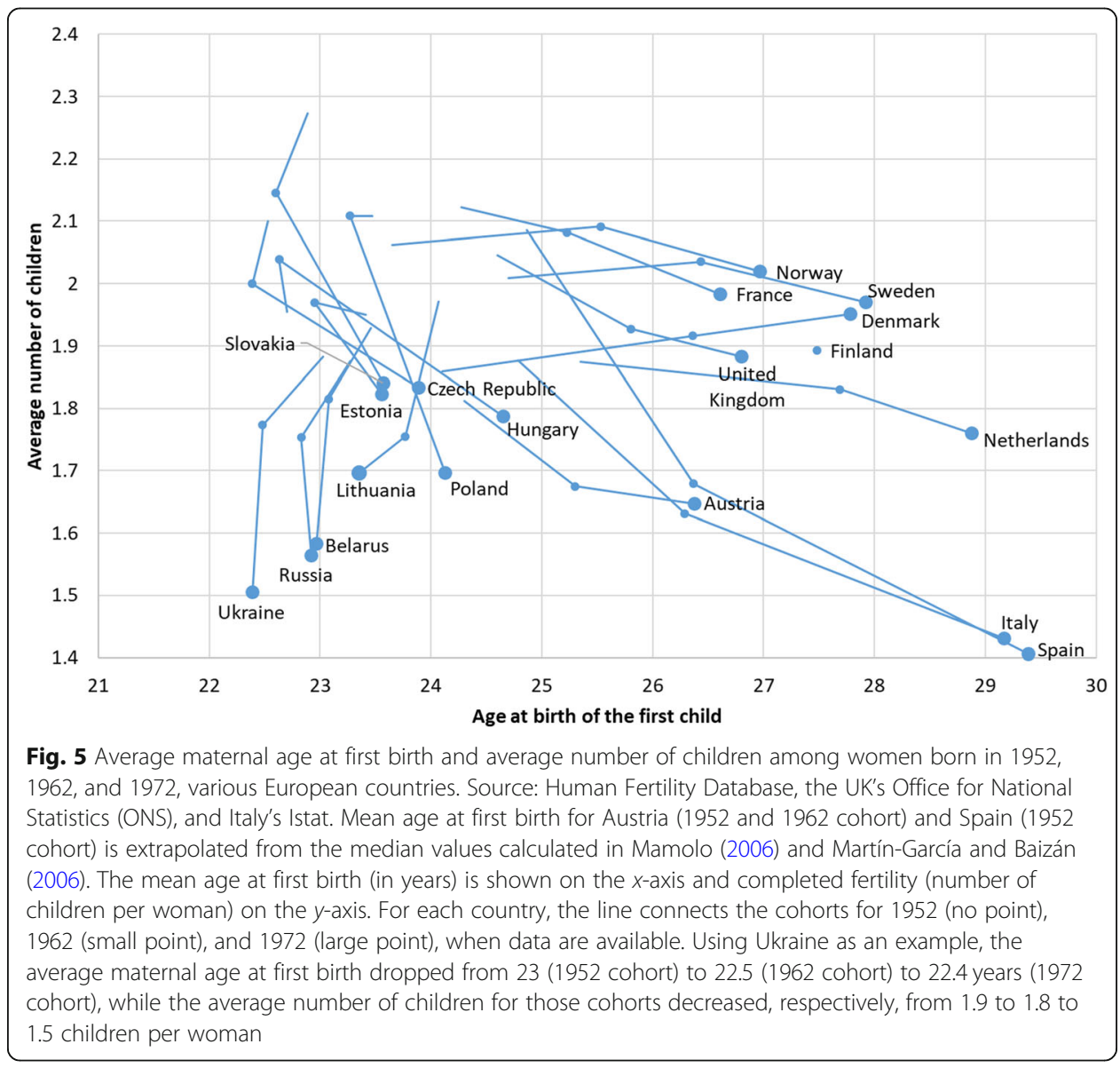


minority, while most other countries are divided into the second and third opposing groups. The second concerns Northern and Western Europe (France, UK, the Netherlands, Norway, Sweden, Denmark, and Finland), where the average number of children per woman either remains at a high level or decreases slightly, while first births are greatly delayed. The third group consists of the remaining Central and Eastern European countries, where the average age at first birth increases slightly or even decreases slightly, while the final number of children falls sharply and reaches levels lower than in Northern or Western Europe.

The contrast between the three groups becomes clearer when we no longer represent the rates and mean ages but their variations for the different countries (Fig. 6). Between the 1952 and 1972 birth cohorts in all countries, the mean age at first birth increased and the mean total number of children decreased, although exceptions take place in some Eastern European countries (Lithuania, Russia, Belarus, and Ukraine, where average first births occur earlier in recent cohorts) and in Denmark (where fertility increased). However, observing both trends together for different countries reveals no dose-response relationship (the longer the delay, the greater the decline). On the contrary, and with the exception of Italy and Spain, a positive relationship clearly exists between changes in maternal age at first birth and in average number of children, as countries with the greatest delays are those with more limited declines.

The mean number of children per woman is the product of two factors: the proportion of women becoming mothers multiplied by the average number of children among mothers. Each factor may be related to age at first birth. If, for example, couples wait longer before deciding to have a child, this can result in both a delay in childbearing and an increase in the proportion of women remaining involuntarily childless (and therefore a decrease in the proportion of women becoming mothers).

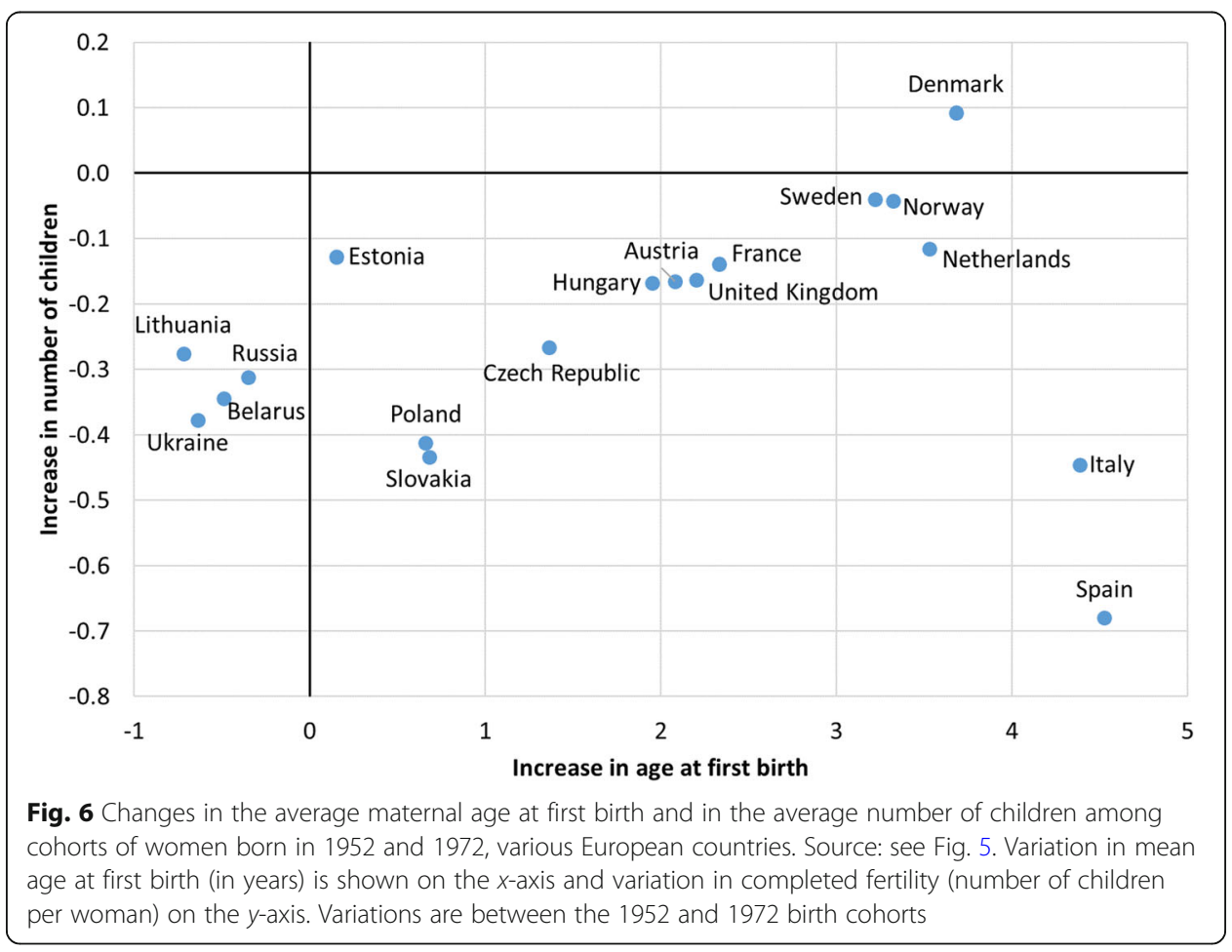


In a cross-sectional perspective, each birth cohort exhibits a strong negative correlation between maternal age at first birth and the proportion of women becoming mothers: women in Central and Eastern European countries become mothers early and few remain childless, while first births in Northern and Western European countries occur both later and less frequently (Sobotka, 2003, 2017). Moreover, having a first child later gives mothers less time to have several children; however, the opposite relationship is observed when comparing countries, as many women in Central and Eastern Europe become mothers but mothers have fewer children on average (Zeman, Beaujouan, Brzozowska, \& Sobotka, 2017).

Regarding the evolution from one cohort to the next, the variation in the proportion of women becoming mothers between the 1952 and 1972 cohorts is very similar in the different European countries, meaning specifically that the variation has no relationship with the increase in mean age (Fig. 7). One may reasonably hypothesize that the biological constraint has been slightly reduced thanks to the use of medically assisted reproduction (Leridon, 2004), while the proportion of voluntarily childless women (and couples) has increased (te Velde et al., 2012).

The relationship between later first births and change in average mother's completed fertility is much more pronounced: the average number of children per mother has remained constant in countries where the age at first birth has increased, while the number of higher-order births has decreased in countries where first births continue to occur early (Fig. 8). Therefore, the general changes across Europe do not at all reflect any individual risk of having fewer children among women with a late first birth.

Cohort fertility trends reflect the absence of a relationship between the decline before and increase after age 30 (Fig. 9), which has already been observed for the years 1996 and 2016. The fertility decline before age 30 is a widespread phenomenon, while the increase over age 30 occurs in Western and Northern European countries but not in those of Central and Eastern Europe. All in all, no overall relationship exists between these two developments.

\section{Discussion and conclusion}

Fertility developments over the past 20 years show that the massive and highly widespread phenomenon of delaying first births has had very diverse consequences for fertility rates. From an individual perspective, people can now have children at older ages after not having them when they were young. However, delaying births can also lead to pursuing other life projects and alternatives to parenthood, thus increasing the likelihood of renouncing or having difficulty in having children later. In most of the countries we observed, the decrease in fertility before age 30 between the 1952 and 1972 birth cohorts was accompanied by an increase in fertility after age 30 between these two cohorts. However, in a few Eastern European countries, the fertility at older ages decreased even further. At the country level, women tend to catch up, although variations exist between countries.

A comparison of countries challenges the "delay-lack of catch up" perspective based on individual-level analyses, as those countries where we observe more postponement rarely experience the greatest drop in total fertility rate. On the contrary, many of the countries with a large decline in early childbearing see the greatest increase in the number of live births at later ages. Thus, fertility trends after age 30 apparently respond to 


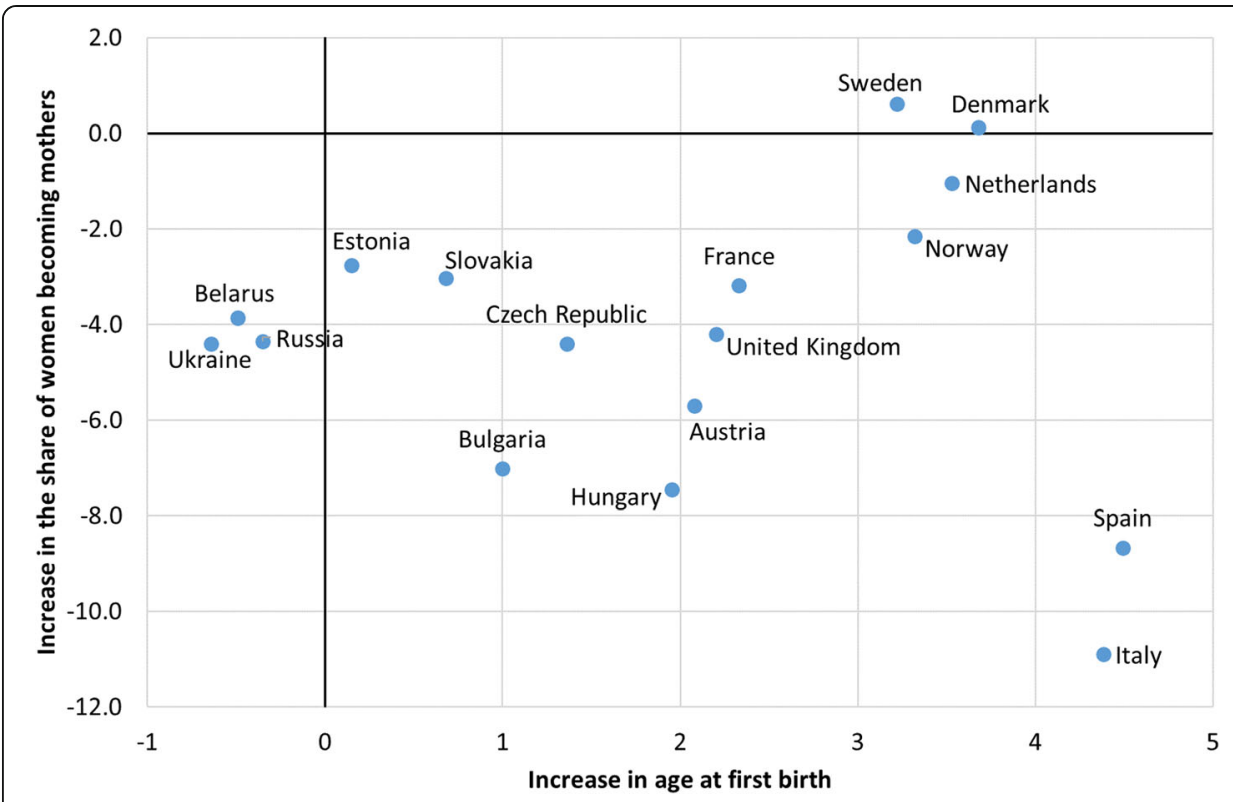

Fig. 7 Changes in the average maternal age at first birth and the proportion of mothers among the 1952 and 1972 cohorts of women. Source: for age at first birth, see Fig. 5; for the proportion of women becoming mothers, Sobotka (2017) and the European Fertility Datasheet (Sobotka et al., 2015). The variation in age at first birth (in years) is shown on the $x$-axis and the variation in the proportion of women becoming mothers (in \%) on the $y$-axis. Variations are between the 1952 and 1972 birth cohorts

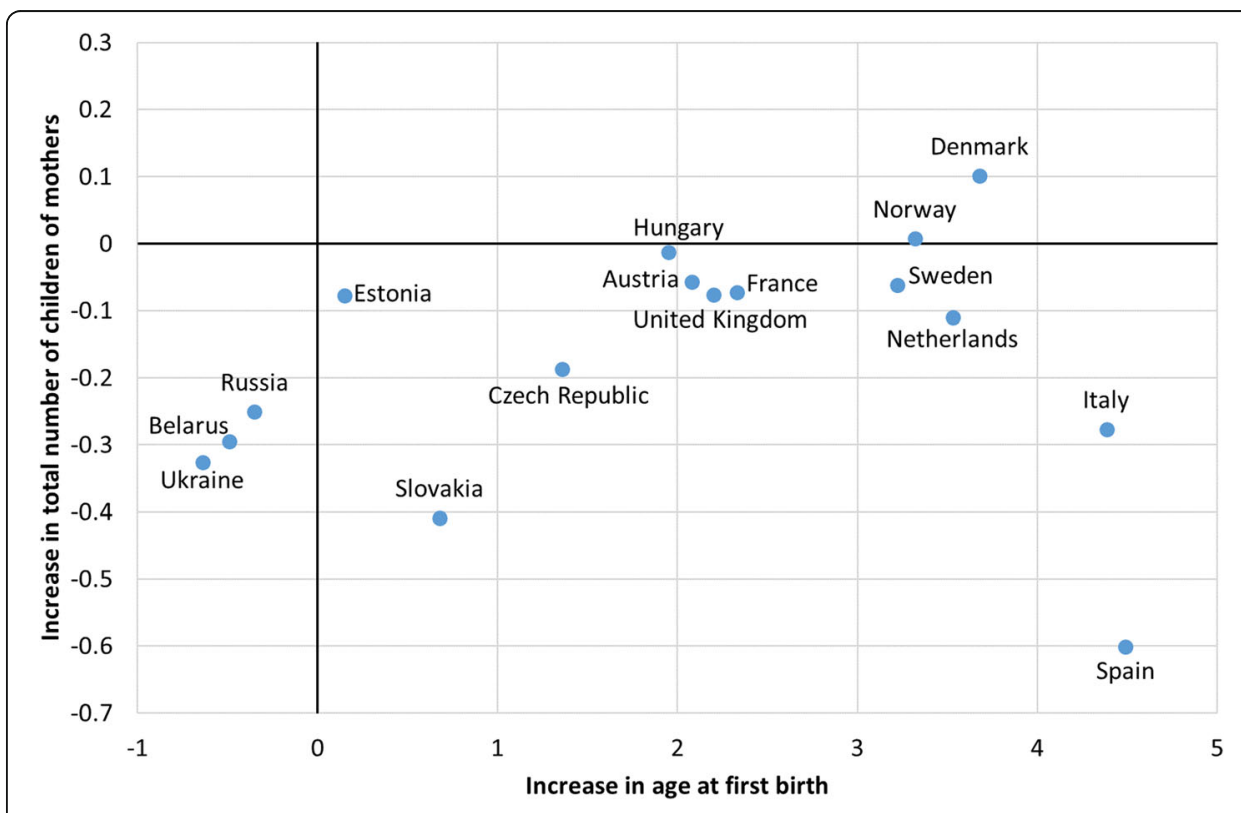

Fig. 8 Changes in the average maternal age at first birth and in the average number of children per mother born in 1952 and 1972. Source: see Figs. 5 and 6. The variation in age at first birth (in years) is shown on the $x$-axis and that of mothers' completed fertility (number of children per mother) on the $y$-axis. Variations are between the 1952 and 1972 birth cohorts 


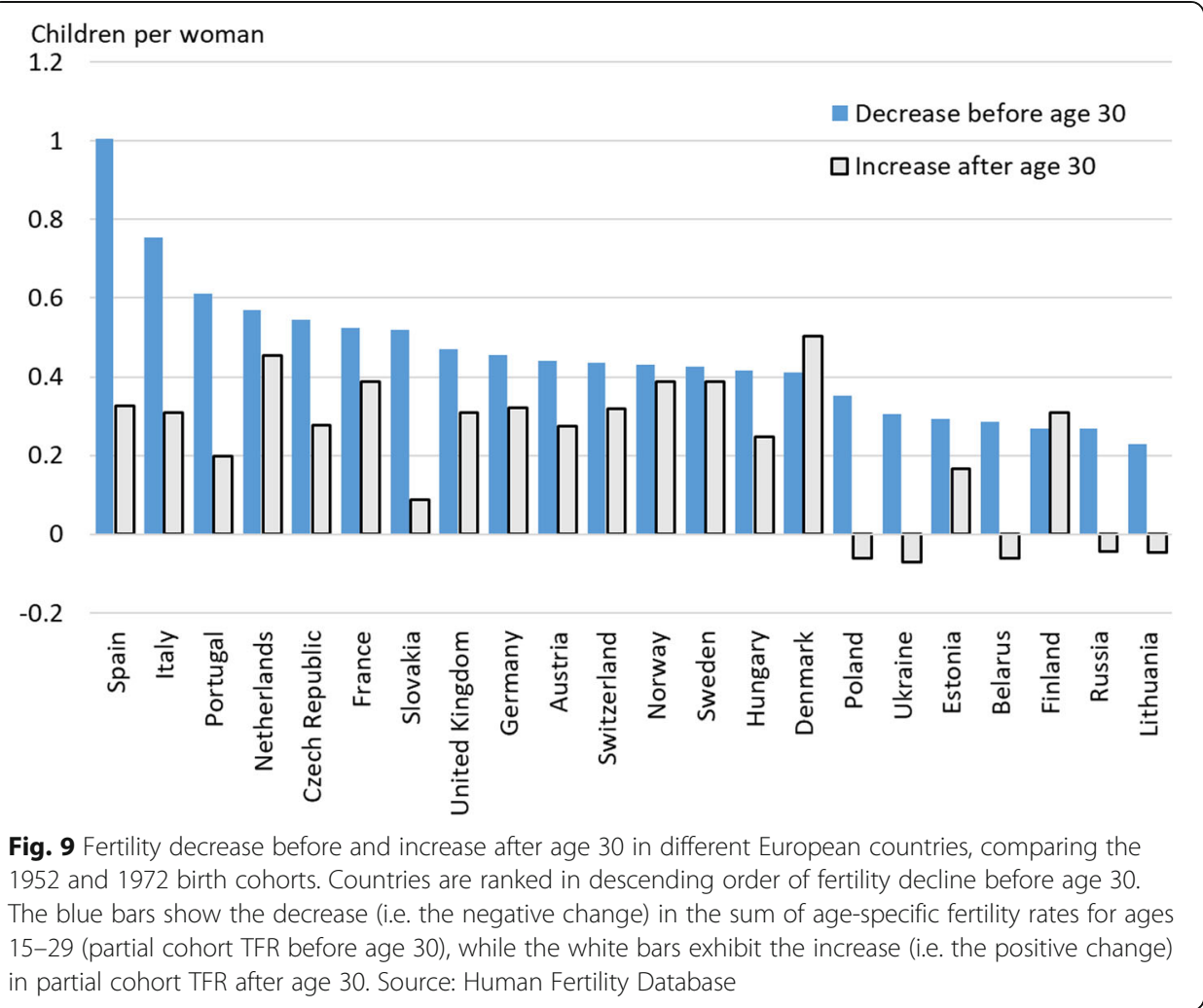

completely different rationales in very dissimilar country contexts. We will attempt to offer some explanation for this.

Let us first turn to the contraceptive confidence hypothesis of Ní Bhrolcháin (1988), who assumes reverse causality at the individual level. This author speculates that because efficient contraception made it possible to avoid having too many children, some young European couples in the 1970s chose to have their first child at young ages due to their feeling confident that they would not have more than they wished. This served to explain the positive relationship between fertility at young ages and the availability of contraception. Similarly, we might assume that anticipating a good work-life balance could lead couples to delay the birth of their first child in anticipation of securing a better and more stable professional position, thus allowing them to take advantage of the inherent benefits that such a position offers to said work-life balance. This was also a reason why some young couples favoured alternatives to having children in the first years of their unions, thus leading to older average ages at first birth.

In countries such as France and the Nordic countries, where childbearing conditions are good and highly compatible with work, women may thus more often postpone childbearing and actually give birth at later ages with the knowledge that having children will likely be easy. This could explain our observations there of greater delay yet constant total fertility over time. Some countries like Italy and Spain experienced postponement in family formation primarily because of adverse economic circumstances in an insufficient welfare state, a situation in which the increase in age at first birth corresponds to having fewer children (Billari et al., 2000). Finally, in Eastern European countries where fertility continued to occur rather early in the period under study, fertility 
rates were also lower. This can be due to a combination of individuals feeling a need to comply with strong parenthood norms while work and parenthood remain relatively incompatible, thus compelling people to have some children early but fewer overall.

Generally speaking, the increase in women engaged in professional activities imposes challenges to reconciling work and family life, which is becoming imperative for women who may be in an advanced stage of their careers after age 30 and lies at the heart of fertility trends (Matysiak et al., 2018). In countries where such reconciliation is the most difficult, fewer women are active in the labour force and fewer children are born, as a choice must be made between working and raising young children. On the other hand, countries with less difficult reconciliation have more active mothers who also have more children (Méda \& Pailhé, 2008; Pailhé, Rossier, \& Toulemon, 2008; Thévenon \& Gauthier, 2011).

The high-fertility countries in our study (nearly two children per woman on average) have a high female labour force participation rate, but they also have more diverse family situations as well as more numerous and fluid family transitions, all of which take the forms of late marriages, unmarried couples, children born outside of marriage, marital breakdown, re-partnering, and the recognition of same-sex couples (Sobotka \& Toulemon, 2008). Giving one example, the break-up of a union leads to a decrease in fertility at any age, while re-partnering can lead to an increase in fertility, especially at older ages. At the country level, these contextual effects therefore seem to largely dominate individual and most notably biological constraints. Thus, for the time being, the fertility trends in various countries are the result of modalities that make it possible to have children in later adulthood, and they do not occur because of declining fertility at young ages or as a direct result of biological constraints on reproduction. This also suggests that the context of childbearing at older ages will be an important driver of future fertility.

\section{Abbreviations}

ONS: Office for National Statistics; TFR: Total fertility rate

\section{Acknowledgements}

This paper is an enriched and revised version of a paper published in French as: Beaujouan E., Toulemon L., "Le retard à la procréation en Europe", Médecine de la Reproduction 2019; 21 (3): 209-219.

Authors' contributions

Both authors contributed equally to the paper. The authors read and approved the final manuscript.

Funding

Éva Beaujouan's work was funded by the Austrian Research Fund (FWF), project "Later Fertility in Europe" P31171-G29.

\section{Availability of data and materials}

Original data sources are referred to in the notes of the figures and are available publicly in the Eurostat repository, https://ec.europa.eu/eurostat/fr/data/database. The numbers represented in the figures can be requested from the authors. 
Received: 14 May 2020 Accepted: 24 November 2020

Published online: 06 January 2021

\section{References}

Arpino, B., Esping-andersen, G., \& Pessin, L. (2015). How do changes in gender role attitudes towards female employment influence fertility? A macro-level analysis. European Sociological Review, 1996, 1-13. https://doi.org/10.1093/esr/jcv002.

Bajos, N., Prioux, F., \& Moreau, C. (2013). L'augmentation du recours répété à I'IVG en France: des enjeux contraceptifs au report de l'âge à la maternité. Revue d'Épidémiologie et de Santé Publique, 61(4), 291-298 http://cat.inist.fr/?aModele= afficheN\&cpsidt=27604848

Balbo, N., Billari, F. C., \& Mills, M. C. (2013). Fertility in advanced societies: a review of research. European Journal of Population, 29(1), 1-38. https://doi.org/10.1007/s10680-012-9277-y.

Beaujouan, É. (2011). La fécondité des deuxièmes unions en France : âges des conjoints et autres facteurs. Population, 66(2), 275-312 http://www.cairn.info/revue-population-2011-2-page-275.htm.

Beaujouan, É., Reimondos, A., Gray, E., Evans, A., \& Sobotka, T. (2019). Declining realisation of reproductive intentions with age. Human Reproduction, 34(10), 1906-1914. https://doi.org/10.1093/humrep/dez150.

Billari, F. C., \& Liefbroer, A. C. (2010). Towards a new pattern of transition to adulthood? Advances in Life Course Research, 15(2-3), 59-75. https://doi.org/10.1016/j.alcr.2010.10.003.

Billari, F. C., Manfredi, P., \& Valentini, A. (2000). Macro-demographic effects of the transition to adulthood: multistate stable population theory and an application to Italy. Mathematical Population Studies, 9(1), 33-63. https://doi.org/10.1080/ 08898480009525494.

Castro, R. (2014). Late-entry-into-motherhood women are responsible for fertility recuperation. Journal of Biosocial Science, 47 , 275-279. https://doi.org/10.1017/S0021932014000121.

Esping-Andersen, G. (2009). The incomplete revolution: adapting welfare states to women's new roles, (1st ed., ). Cambridge: Polity Press.

Frejka, T., \& Sobotka, T. (2008). Overview chapter 1: fertility in europe: diverse, delayed and below replacement. Demographic Research, 19(Special Collection 7), 15-46 http://www.demographic-research.org/special/7/.

Gauthier, A. H. (2002). Les politiques familiales dans les pays industrialisés: y a-t-il convergence? Population, 57(3), 457-484

Goldin, C., \& Katz, L. F. (2002). The power of the pill: oral contraceptives and women's career and marriage decisions. Journal of Political Economy, 110(4), 730-770. https://doi.org/10.1086/340778.

Habbema, J. D. F., Eijkemans, M. J. C., Leridon, H., \& te Velde, E. R. (2015). Realizing a desired family size: When should couples start? Human Reproduction, 30(9), 2215-2221. https://doi.org/10.1093/humrep/dev148.

Insee. (2019). La situation démographique en 2017. État Civil et Estimations de Population - Insee Résultats. https://www.insee. $\mathrm{fr} / \mathrm{fr} / \mathrm{statistiques} / 4136000$.

Jasilioniene, A., Jdanov, D. A., Sobotka, T., Andreev, E. M., Zeman, K., \& Shkolnikov, V. M. (2007). Methods protocol for the human fertility database. HFD, 2015 http://www.humanfertility.org/Docs/methods.pdf.

Kotelchuck, M. (2007). Safe mothers, healthy babies: reproductive health in the twentieth century. In J. W. Ward, \& C. Warren (Eds.), Silent victories: the history and practice of public health in twentieth century America, (pp. 105-134). Oxford: Oxford University Press.

Kreyenfeld, M., Andersson, G., \& Pailhé, A. (2012). Economic uncertainty and family dynamics in Europe: Introduction. Demographic Research, 27, 835-852. https://doi.org/10.4054/demres.2012.27.28.

Leridon, H. (2004). Can assisted reproduction technology compensate for the natural decline in fertility with age? A model assessment. Human Reproduction, 19(7), 1548-1553. https://doi.org/10.1093/humrep/deh304.

Lesthaeghe, R. J. (2010). The unfolding story of the second demographic transition. Population and Development Review, 36(2), 211-251.

Lesthaeghe, R. J. (2016). Following the evolution of fertility in second demographic transition settings: the life- cycle sensitive approach. In H. De Grande, \& H. Vandenheede (Eds.), Back to the roots of demography, (pp. 105-114). Gavere: ZenonPlus.

Liefbroer, A. C., \& Billari, F. C. (2010). Bringing norms back in: a theoretical and empirical discussion of their importance for understanding demographic behaviour. Population, Space and Place, 16(4), 287-305. https://doi.org/10.1002/psp.552.

Luci-Greulich, A., \& Thévenon, O. (2013). The impact of family policies on fertility trends in developed countries. European Journal of Population / Revue Européenne de Démographie, 29(4), 387-416. https://doi.org/10.1007/s10680-013-9295-4.

Mamolo, M. (2006). Union formation, marriage and first birth: convergence across cohorts in Austria, Hungary, Northern Italy and Slovenia? VID Working Papers, WP08/2006.

Martín-García, T., \& Baizán, P. (2006). The impact of the type of education and of educational enrolment on first births. European Sociological Review, 22(3), 259-275. https://doi.org/10.1093/esr/jci056.

Matysiak, A., Sobotka, T., \& Vignoli, D. (2018). The great recession and fertility in Europe: a sub-national analysis. VID Working Papers, WP2018_02. https://doi.org/10.1007/978-3-319-32997-0

Mazuy, M. (2006). Etre prêt-e, être prêts ensemble? Entrée en parentalité des hommes et des femmes en France. Thèse pour l'obtention du diplôme de Doctorat en Démographie, Université Paris 1 - Panthéon-Sorbonne.

Mazuy, M., Barbieri, M., Breton, D., \& D'Albis, H. (2015). L'évolution démographique récente de la France et ses tendances depuis 70 ans. Population, 70(3), 417-486. https://doi.org/10.3917/popu.1503.0417.

Méda, D., \& Pailhé, A. (2008). Fertility: is there a French model? The Japanese Journal of Social Security Policy, 7(2), 31-40 http:// www.ipss.go.jp/webj-ad/webJournal.files/SocialSecurity/2008/winter/JJSSPvol.7no.2_Dec 2008-1 DominiqueMedaandArianePailhe.pdf.

Mills, M. C., Rindfuss, R. R., Mcdonald, P., Velde, E. T., \& Force, E. R. S. T. (2011). Why do people postpone parenthood? Reasons and social policy incentives. Human Reproduction Update, 17(6), 848-860. https://doi.org/10.1093/humupd/dmr026.

Nathan, M., \& Pardo, I. (2019). Fertility postponement and regional patterns of dispersion in age at first birth: descriptive findings and interpretations. Comparative Population Studies, 44, 37-60. https://doi.org/10.12765/CPoS-2019-07en.

Neels, K., \& De Watcher, D. (2010). Postponement and recuperation of Belgian fertility: how are they related to rising female educational attainment? Vienna Yearbook of Population Research, 8, 77-106. https://doi.org/10.1553/ populationyearbook2010s77. 
Neels, K., Murphy, M., Ní Bhrolcháin, M., \& Beaujouan, É. (2017). Rising educational participation and the trend to later childbearing. Population and Development Review, 43(4), 667-693. https://doi.org/10.1111/padr.12112.

Neels, K., Theunynck, Z., \& Wood, J. (2012). Economic recession and first births in Europe: recession-induced postponement and recuperation of fertility in 14 European countries between 1970 and 2005. International Journal of Public Health, 58(1), 43-55. https://doi.org/10.1007/s00038-012-0390-9.

Ní Bhrolcháin, M. (1988). The contraceptive confidence idea: an empirical investigation. Population Studies, 42, 205-225.

Ní Bhrolcháin, M., \& Beaujouan, É. (2012). Fertility postponement is largely due to rising educational enrolment. Population Studies, 66(3), 311-327. https://doi.org/10.1080/00324728.2012.697569.

Ní Bhrolcháin, M., \& Toulemon, L. (2005). Does postponement explain the trend to later childbearing in France? Vienna Yearbook of Population Research, 83-107.

Nicoletti, C., \& Tanturri, M. L. (2008). Differences in delaying motherhood across European countries: empirical evidence from the ECHP. European Journal of Population - Revue Européenne de Démographie, 24(2), 157-183. https://doi.org/10.1007/ s10680-008-9161-y.

Pailhé, A., Rossier, C., \& Toulemon, L. (2008). French family policy: long tradition and diversified measures. Vienna Yearbook of Population Research, 19(1), 149-164. https://doi.org/10.1553/populationyearbook2008s149.

Philipov, D. (2009). The effect of competing intentions and behaviour on short-term childbearing intentions and subsequent childbearing. European Journal of Population - Revue Européenne de Démographie, 25(4), 525-548. https://doi.org/10.1007/ s10680-009-9197-7.

Prioux, F. (2004). Évolution des principaux indicateurs de périnatalité en France. Santé, Société et Solidarité, 3(1), 11-23. https:// doi.org/10.3406/oss.2004.1218.

Rybińska, A., Tocchioni, V., Matysiak, A., Vignoli, D., \& Mynarska, M. (2012). Paths into childlessness over the life course. Results of the sequence analysis for Italy and Poland. European Population Conference - Side Meeting.

Sánchez-Barricarte, J. J., \& Fernández-Carro, R. (2007). Patterns in the delay and recovery of fertility in Europe. European Journal of Population - Revue Européenne de Démographie, 23(2), 145-170. https://doi.org/10.1007/s10680-006-9114-2.

Sobotka, T. (2003). Tempo-quantum and period-cohort interplay in fertility changes in Europe. evidence from the Czech Republic, Italy, the Netherlands and Sweden. Demographic Research, 8, 151-214 http://www.demographic-research.org/ Volumes/Nol8/6/8-6.pdf.

Sobotka, T. (2016). The European middle way? Low fertility, family change, and gradual policy adjustments in Austria and the Czech Republic. In R. R. Rindfuss, \& M. K. Choe (Eds.), Low fertility, institutions, and their policies: variations across industrialized countries, (pp. 131-163). Cham: Springer International Publishing Switzerland. https://doi.org/10.1007/978-3319-32997-0_6

Sobotka, T. (2017). Childlessness in Europe: reconstructing long-term trends among women born in 1900-1972. In M. Kreyenfeld, \& D. Konietzka (Eds.), Childlessness in Europe: contexts, causes, and consequences, (pp. 17-53). Springer.

Sobotka, T., Skirbekk, V., \& Philipov, D. (2011). Economic recession and fertility in the developed world. Population and Development Review, 37(2), 267-306. https://doi.org/10.1111/j.1728-4457.2011.00411.x.

Sobotka, T., \& Toulemon, L. (2008). Changing family and partnership behaviour: common trends and persistent diversity across Europe. Demographic Research, 19(Special Collection 7), 85-138.

Sobotka, T., Zeman, K., Lesthaeghe, R. J., Frejka, T., \& Neels, K. (2011). Postponement and recuperation in cohort fertility: Austria, Germany and Switzerland in a European context. Comparative Population Studies, 36(2-3), 417-452. https://doi. org/10.4232/10.CPoS-2011-16en.

Sobotka, T., Zeman, K., Potančoková, M., Eder, J., Brzozowska, Z., Beaujouan, É., \& Matysiak, A. (2015). European fertility datasheet 2015. Vienna Institute of Demography.

te Velde, E. R., Habbema, J. D. F., Leridon, H., \& Eijkemans, M. J. C. (2012). The effect of postponement of first motherhood on permanent involuntary childlessness and total fertility rate in six European countries since the 1970s. Human Reproduction, 27(4), 1179-1183. https://doi.org/10.1093/humrep/der455.

Testa, M. R., \& Rampazzo, F. (2018). From intentions to births: Paths of realization in a multidimensional life course. Vienna Yearbook of Population Research, 16, 177-198. https://doi.org/10.1007/s10551-011-0925-7.

Thévenon, O., \& Gauthier, A. H. (2011). Family policies in developed countries: a "fertility-booster" with side-effects. Community, Work \& Family, 14(2), 197-216. https://doi.org/10.1080/13668803.2011.571400.

Thomson, E., Lappegård, T., Carlson, M. J., Evans, A., \& Gray, E. (2014). Childbearing across partnerships in Australia, the United States, Norway, and Sweden. Demography, 51, 485-508. https://doi.org/10.1007/s13524-013-0273-6.

Thomson, E., Winkler-Dworak, M., Spielauer, M., \& Prskawetz, A. (2012). Union instability as an engine of fertility? A microsimulation model for France. Demography, 49(1), 175-195. https://doi.org/10.1007/s13524-011-0085-5.

Tomkinson, J. (2019). Age at first birth and subsequent fertility: the case of adolescent mothers in France and England and Wales. Demographic Research, 40(April), 761-798. https://doi.org/10.4054/DemRes.2019.40.27.

Toulemon, L., \& Leridon, H. (1992). Maîtrise de la fécondité et appartenance sociale: contraception, grossesses accidentelles et avortements. Population, 47(1), 1-45 http://www.jstor.org/stable/1533631.

Toulemon, L., \& Mazuy, M. (2001). Les naissances sont retardées mais la fécondité est stable. Population, 56(4), 611-644.

Vallin, J., \& Meslé, F. (2004). Convergences and divergences in mortality: a new approach of health transition. Demographic Research, Special, 2, 11-44. https://doi.org/10.4054/demres.2004.s2.2.

Van Bavel, J., Jansen, M., \& Wijckmans, B. (2012). Has divorce become a pro-natal force in Europe at the turn of the 21st century? Population Research and Policy Review, 31(5), 751-775. https://doi.org/10.1007/s11113-012-9237-6.

Zeman, K., Beaujouan, É., Brzozowska, Z., \& Sobotka, T. (2017). Cohort fertility decline in low fertility countries: decomposition using parity progression ratios. Vienna Institute of Demography Working Papers. http://www.humanfertility.org/cgi-bin/reports.php.

\section{Publisher's Note}

Springer Nature remains neutral with regard to jurisdictional claims in published maps and institutional affiliations. 